\title{
AS COMPANHIAS COLONIZADORAS NO PROCESSO DA IMIGRAÇÃO ITALIANA EM TERRITORIALIDADES DO VALE DO TAQUARI/RIO GRANDE DO SUL ${ }^{1}$
}

\author{
Janaine Trombini* \\ Luís Fernando da Silva Laroque** \\ Ana Paula Castoldi***
}

\begin{abstract}
RESUMO: Os imigrantes italianos chegaram ao Brasil no final do século XIX. Na Província de São Pedro do Rio Grande do Sul, foram destinados à porção territorial situada na Encosta Superior do Planalto, entre os vales do Rio Caí e das Antas e, posteriormente, em territórios atualmente denominados de Vale do Taquari. O estudo tem como objetivo analisar a influência de companhias colonizadoras no processo de colonização dos imigrantes italianos e seus descendentes em territórios do Vale do Taquari. O método caracteriza-se por uma abordagem qualitativa com análise de conteúdo no que se refere a dados coletados na revisão bibliográfica e pesquisa documental. As companhias colonizadoras evidenciadas no processo de colonização foram Bastos \& Companhia, Cia Colonizadora Rio-Grandense e Tchener e Cia, as quais existiram desde o final do século XIX até meados da década de 1920.
\end{abstract}

PALAVRAS-CHAVE: Companhias colonizadoras; Ocupação; Descendentes de italianos; Vale do Taquari.

\section{The colonizing companies in the italian immigration process in territorialities of the Taquari Valley / Rio Grande do Sul}

ABSTRACT: Italian immigrants arrived in Brazil in the end of the 19th century. In São Pedro do Rio Grande do Sul Province, they were assigned to the territorial portion located on the upper slope of the plateau, between the valleys of the Caí River and the Antas River and after in the territory denominated Taquari Valley. This study aims to analyze the influence of the colonizing companies in the process of colonization of Italian immigrants and their descendants in territories of the Taquari Valley. The method is characterized by a qualitative approach with content analysis regarding to the data collected in the bibliographic review and documentary research. The colonizing companies evidenced in the colonization process were Bastos \& Companhia, Cia Colonisadora Rio-Grandense and Tchener e Cia, which existed from the end of the 19th century until the mid-1920s.

KEYWORDS: Colonizing companies; Occupation; Italian descendants; Taquari Valley.

\section{Las compañías colonizadoras en el proceso de la inmigración italiana en territorialidades del Valle del Taquari / Rio Grande del Sur}

RESUMEN: Los inmigrantes italianos llegaron a Brasil a finales del siglo XIX. En la Provincia de San Pedro del Río Grande del Sur se destinaron a la porción territorial situada en la cuesta superior de la meseta, entre los valles del río Caí y de las Antas y posteriormente en territorios actualmente denominados Valle del Taquari. El estudio tiene como objetivo analizar la influencia de compañías colonizadoras en el proceso de colonización de los inmigrantes italianos y sus descendientes en territorios del Valle del Taquari. El método se caracteriza por un abordaje cualitativo con análisis de contenido en lo que se refiere a datos recogidos en la revisión bibliográfica e investigación documental. Las compañías colonizadoras destacadas en el proceso de colonización fueron Bastos \& Compañía, Cia Colonisadora Rio-Grandense y Tchener y Cia, las cuales existieron desde el final del siglo XIX hasta mediados de la década de 1920.

PALABRAS CLAVE: Compañías colonizadoras; Ocupación; Descendientes de italianos; Valle del Taquari.

* Mestre em Ambiente e Desenvolvimento pela UNIVATES. Atualmente, doutoranda do Programa de PósGraduação em Ambiente e Desenvolvimento da UNIVATES. Contato: Av. Avelino Talini, 171, Universitário, CEP: 95900-000, Lajeado - RS, Brasil. E-mail: janainet@ universo.univates.br

** Doutor em História. Atualmente é professor e pesquisador do Programa de Pós-Graduação em Ambiente e Desenvolvimento e do Curso de História da UNIVATES. E-mail: lflaroque@univates.br.

*** Graduada em História-Licenciatura pela UNIVATES. E-mail: anapaulacastoldi13@hotmail.com. 


\section{Introdução}

Conforme o estudo de Iotti (1996), a imigração italiana, que ocorreu no decorrer dos séculos XIX e XX para o Brasil, está diretamente ligada à expansão do capitalismo e às transformações das estruturas políticas, econômicas e sociais vigentes na Europa. O fluxo migratório italiano vinculou-se às mudanças estruturais principalmente em decorrência do sistema político e econômico e às novas formas de produção que seriam adotadas.

A porção territorial norte da Itália foi a região que forneceu o maior contingente de emigrantes para o Brasil. Entre 1876 a 1901, emigraram do reino italiano 5.792 .546 pessoas, sendo a maioria de Piemonte e da região de Vêneto (HERÉDIA, 2004). Esse processo de envio de italianos para o Brasil amenizou questões políticas, como o processo de unificação, e também econômicas, pois a empresa emigratória gerava lucros para as companhias de colonização e para os bancos. A venda de passagens, de alimentação e o auxílio para os parentes movimentavam a economia e proporcionavam melhorias sociais (GIRON; HERÉDIA, 2007).

O processo imigratório para o Brasil é orientado por dois sentidos: um oficial, a colonização, que visava ocupar e povoar zonas até então desocupadas e distantes por estrangeiros; o outro, particular, chamado de imigração, estimulado pelo governo que queria a obtenção de braço livre para a grande lavoura, como mão de obra barata (BARROS; LANDO, 1996).

A vinda de imigrantes italianos relacionou-se à política de imigração e de colonização do Governo Imperial brasileiro. Concomitante, a elite brasileira apoiava o sentido de branquear a população, que definia a qualidade do imigrante europeu como melhor para atender os interesses sociais (IOTTI, 1996). Por outro lado, vale salientar que o Brasil tinha braços para dar continuidade às atividades produtivas com os nacionais livres e os negros escravizados, muitos dos quais estavam sendo libertos. Contudo, a opção foi poupar o investimento em escravos e o trabalho nacional para as funções essenciais, como as tarefas complementares ou perigosas (BEIGUELMAN, 1985).

Entre 1875 a 1935, entraram no Brasil cerca de 1,5 milhão de italianos, que se expandiram e fundaram núcleos populacionais pelas Províncias de São Paulo, Paraná, Santa Catarina e São Pedro do Rio Grande do Sul. Desse total de imigrantes, aproximadamente 1 milhão e 200 mil foi para São Paulo; 60 mil, para Minas Gerais; outros, para Espírito Santo; 20 mil foram para o Paraná; 25 mil, para Santa Catarina; 100 mil para o Rio Grande do Sul (DE BONI; COSTA, 1991). 
Nesse sentido, o estudo tem como objetivo analisar a influência de companhias colonizadoras no processo de colonização dos imigrantes italianos e seus descendentes em territórios do Vale do Taquari. Trata-se de um trabalho de cunho bibliográfico e de pesquisa documental realizada em arquivos de Porto Alegre e do Vale do Taquari. As informações foram analisadas com base em teóricos da etnicidade e da territorialidade, cujo método dedutivo foi utilizado para análise dos dados obtidos e pesquisados.

Sendo um objeto de estudo que tem escala reduzida por tratar-se de um determinado espaço territorial - Vale do Taquari - e um empreendimento comercial - Companhias Colonizadoras no Rio Grande do Sul, a micro-história torna-se relevante como abordagem de análise. Nesse sentido, temos:

\begin{abstract}
Mediante o estudo intensivo e aproximado de configurações e processos sociais, a abordagem micro-histórica assume, portanto, a tarefa de compreender como essas configurações se constituem e convivem [...]. Ela procura também entender a maneira como movimentos ou transformações coletivos são possíveis, mas não a partir desses movimentos em si e da capacidade autorrealizadora que se lhes imputa, e sim da parte que cada ator toma neles [...] (REVEL, 2010, 440).
\end{abstract}

Por conseguinte, através do estudo das Companhias Colonizadoras, observa-se a sua importância na modificação e nas alterações em diversos espaços, bem como, nos processos sociais, em virtude da migração de pessoas e do seu estabelecimento em territórios do atual Vale do Taquari. Corroborando com isso, Giovanni Levi (1992) chama atenção para o fato de que a micro-história não trata somente de casos individuais, uma vez que sua análise precisa estar conectada em contextos gerais.

O Vale do Taquari, denominação geopolítica criada a partir dos Conselhos Regionais de Desenvolvimento - COREDES ${ }^{2}$, composto por trinta e seis municípios membros, localizase na porção centro-leste do território do Rio Grande do Sul. A região apresenta uma diversidade de características econômicas e socioculturais. Economicamente, o Vale é composto por pequenas propriedades rurais situadas nos municípios com menor proporção populacional, como também, pela produção industrial em centros urbanos maiores, com ênfase na indústria de alimentos e no setor calçadista.

Do ponto de vista sociocultural, a região é composta por diversos grupos étnicos, como indígenas, principalmente os Kaingang, descendentes de africanos e de europeus. Este último grupo inclui, principalmente, os açorianos, os alemães, os italianos. Nos dias atuais, a região ainda conta com grupos de imigrantes haitianos e senegaleses, além de outros grupos em menor escala, tais como, descendentes de poloneses, libaneses, franceses e holandeses. 
Torna-se importante refletir acerca do conceito de território, de região e de microrregião, já que se trata de um estudo que envolve municípios e territorialidades que foram colonizados por italianos e seus descendentes no Vale do Taquari. A definição de território, segundo Cabral (2007, p. 151), na geografia tradicional remete a “[...] determinada porção da superfície terrestre que é apropriada e ocupada por um grupo humano, como um espaço concreto em si (com seus atributos naturais e sociais)". Contudo, na geografia renovada, as concepções mais difundidas de território no século $\mathrm{XX}$ consistem na concretização da ação do homem no espaço e a apropriação sobre determinada área e espaço concreto entre si.

Segundo Moreira (2007), o conceito de região, a partir de indicadores econômicos e físicos tomados pelas escolas geográficas, é utilizado para demarcação de limites rigorosamente precisos de um espaço territorial. No entender de Haesbert (2010, p. 6), “a regionalização deve estar sempre articulada numa análise centrada na ação dos sujeitos que produzem o espaço e na interação que eles estabelecem, seja com a primeira, seja com a segunda". Por isso, compreende-se região como um espaço no qual pode-se fazer um recorte para melhor situar-se e também orientar-se dentro dele, cabendo assim determiná-lo através de processos globalizantes ou por situações sociais.

Por microrregião, conforme IBGE (2008), compreende-se o espaço de uma estrutura de produção agropecuária, industrial, extrativismo mineral ou pesca. Expressa a divisão e a organização do espaço regional em nível micro ou local.

\section{A imigração italiana no Rio Grande do Sul e as companhias colonizadoras}

No Rio Grande do Sul, os imigrantes italianos chegaram a partir de meados da década de setenta do século XIX até início do século XX, com a proposta de trabalhar na agricultura; contudo, a aquisição devia ocorrer por meio da compra. A Província oferecia boas condições de realizar uma política imigratória e tinha meios para começar o processo de receber, organizar e assentar as famílias nos lotes coloniais. As terras situavam-se na Encosta Superior da Serra do Nordeste da Província de São Pedro do Rio Grande do Sul, localizada entre as bacias dos rios Caí, Antas e Taquari, coberto de matas, com difícil acesso e dificuldades para exploração econômica.

A Lei de Terras de 1850 acarretou mudanças que também impactaram na colonização italiana no Brasil, uma vez que, se as terras, que só poderiam ser adquiridas através da 
compra, não fossem ocupadas, deveriam voltar ao governo Imperial. A ocupação das áreas agrícolas no Rio Grande do Sul obedecia a condições para a colonização: serem ocupadas por não escravos e transferidas aos colonos somente com a efetivação e aproveitamento das terras por um período de cinco anos (FREITAS JÚNIOR, 1882).

Segundo esta lei de n. 601 de 18 de setembro de 1850:

[...] as terras devolutas no Império, acerca das que são possuídas por títulos de sesmaria sem preenchimento das condições legais, bem como, por simples títulos de posse mansa e pacifica; e determina que, medidas e demarcadas as primeiras, sejam elas cedidas a título oneroso, assim para empresas particulares, como para o estabelecimento de colônias de nacionais e de estrangeiros, autorizado o Governo a promover a colonização estrangeira na forma que se declara.

Outra lei relevante para a posse de terras é a Lei 504, de 30 de janeiro de 1854, cujo Art. 64 diz o seguinte:

À medida que se for verificando a medição e demarcação dos territórios, em que devem ser divididas as terras devolutas, os Delegados do Director Geral das Terras Públicas remeterão ao dito Diretor os mapas da medição e demarcação de cada um dos ditos territórios, acompanhados dos respectivos memoriais, e de informação de todas as circunstâncias favoráveis, ou desfavoráveis ao território medido, e do valor de cada braça quadrada com atenção aos preços fixados no $2^{\circ}$ do Artigo 14 da Lei $\mathrm{N}^{\circ}$ 601 de 18 de setembro de 1850 .

No Brasil do século XIX, bem como, na Província de São Pedro do Rio Grande do Sul, o projeto envolvendo a colonização recorria a Companhias Públicas e Particulares ${ }^{3}$ no que se refere à distribuição ou comercialização de terras. Portanto, até a metade do século XIX, as terras eram estabelecidas pelo governo para a instalação de estrangeiros, a fim de aumentar a lavoura e a população. A partir de 1850, com a Lei de Terras, as terras passaram a ser comercializadas por companhias oficiais ou particulares, que tinham autorização para cultivar os terrenos considerados baldios, devolutos ou abandonados (IOTTI, 2001).

De acordo com Giron e Herédia (2007), os italianos chegaram após 1870, em áreas da porção nordeste do território do Rio Grande do Sul, local caracterizado por uma abundância de mato. Recebiam auxílio governamental, como alimentação, sementes e instrumentos agrícolas, com vista a posteriormente serem ressarcidos com as terras adquiridas. As primeiras colônias oficiais fundadas no Rio Grande do Sul foram Conde d’Eu (1875), Dona Isabel (1875), Caxias (1875) e Silveira Martins (1877), que, segundo Manfroi (2001), são considerados os quatro principais centros da imigração italiana.

A partir de então, inicia-se o desenvolvimento econômico e sociocultural das regiões ocupadas e cultivadas pelos imigrantes italianos e por seus descendentes. Entre 1875 e 1914, 
entraram no Rio Grande do Sul aproximadamente 76.168 imigrantes, que foram conduzidos para as terras próximas aos Campos de Cima da Serra, à Depressão Central e à Zona da Campanha.

Conforme Frosi e Mioranza (1975), a distribuição dos movimentos e períodos da imigração italiana, iniciados em 1875, na Região Nordeste do Rio Grande do Sul, estenderamse para outros territórios do nordeste do estado até 1892, com a fundação de outras colônias como Antônio Prado, Alfredo Chaves e Guaporé. Para além, outras migrações internas surgiram até 1910 com o expansionismo espontâneo para outras regiões do Rio Grande do Sul e para outros estados como Santa Catarina e Paraná.

Segundo Costa (1986), o imigrante italiano veio em busca de terras para cultivo, mas, ao chegar ao Brasil, depara-se com outra situação. O sonho de encontrar territórios férteis se desfez quando o imigrante visualizou as regiões montanhosas e reduziu seus cultivos nas encostas das montanhas. Com o passar do tempo, o imigrante italiano adaptou-se ao território e cultivou o solo, introduzindo culturas perenes, como, por exemplo, os parreirais.

Próximo à Colônia Caxias, foram demarcadas outras três colônias: Nova Pádua (1884), Alfredo Chaves (1884) e São Marcos (1885). Em 1877, foi criada, em direção ao centro da província, a Colônia de Silveira Martins (1877), além de outras, que se expandiram para o norte e para o sul, como Antônio Prado (1889), Ernesto Alves (1890) e Guaporé (1892). A proclamação da República no Brasil e a expansão da ferrovia formaram possibilidades no sentido de também adquirir outras terras produtivas e baratas no planalto. Vale ainda salientar que muitos imigrantes e seus filhos partiram das velhas colônias, localizadas na porção nordeste do Rio Grande do Sul para ocupar terras ao norte e também em Santa Catarina e no Paraná (FAVARO, 2006).

Registros relativos à entrada de colonos na Província de São Pedro do Rio Grande do Sul, no final da década de 1890 (QUADRO 1), revelam um número de 3.592 imigrantes italianos nas colônias mais antigas:

Quadro 1 - Entrada de imigrantes italianos em 1888

\begin{tabular}{c|c}
\hline Silveira Martins & 709 \\
Caxias e Antônio Prado & 818 \\
Alfredo Chaves e D. Isabel & 2065 \\
\hline
\end{tabular}

Fonte: Arquivo Histórico do Rio Grande do Sul - Livro da Estatística dos Imigrantes que entraram na Província do Rio Grande do Sul durante o ano de 1888.

Os colonos imigrantes italianos eram direcionados para os lotes em regiões 
montanhosas que lhes eram destinados pelo diretor da colônia, ou que o próprio imigrante havia escolhido, pois muitos de seus parentes já estavam estabelecidos em terras que haviam adquirido. O lote era concedido ao colono imigrante italiano mediante pagamento de cinco anos. Assim que chegava às terras destinadas à colonização, conforme Costa (1986), o imigrante logo construía alguma choupana para proteger-se das intempéries e de animais selvagens.

\section{As companhias colonizadoras no Vale do Taquari}

No final do século XIX, os imigrantes italianos estabeleceram-se no Vale do Taquari, vindos das antigas colônias da Região Nordeste do Rio Grande do Sul, à procura de novas terras para colonização (KARAM, 1992). Esse processo culminou numa formação étnicocultural da região bastante diversificada. Esta região, que tradicionalmente era território indígena, passou a ser colonizada por portugueses, que trouxeram os negros, seguidos pelos açorianos e pelos alemães e, posteriormente, chegaram os italianos.

A pluralidade cultural e étnica do Vale do Taquari pode ser pensada a partir dos pressupostos de Barth (2000), que salienta que a etnicidade se define nas fronteiras. Ou seja, quando há o contato entre grupos distintos, as fronteiras por meio das diferenças tendem a emergir. Salienta, ainda, que dentro de um grupo étnico, o conteúdo, os traços culturais podem modificar-se; todavia, os indicativos de pertencimento continuam os mesmos, sendo percebidos através dos sinais diacríticos das fronteiras, situação que podemos aplicar aos italianos em relação aos demais grupos étnicos do Vale do Taquari.

A ocupação deste vale foi possibilitada pela apropriação destes grupos étnicos e pela compra de terras por intermédio das companhias colonizadoras em territórios nas encostas, na "região alta", caracterizada por planalto e montanha, situados na Bacia Hidrográfica ${ }^{4}$ TaquariAntas no Vale do Taquari. O território do Vale do Taquari é uma região situada na porção centro-leste do Rio Grande do Sul, segundo já referido, formada por 36 municípios, totalizando uma área de 4.821,1 $\mathrm{Km}^{2}$. O território está dividido em seis microrregiões: norte, sul, leste, oeste, centro e centro-oeste, conforme mapa (FIGURA 1). Em 2013, a Fundação de Economia e Estatística (FEE) estimou para a Região uma população de 334.438 habitantes (3,08\% da população gaúcha), sendo a grande maioria descendente de alemães, italianos ou açorianos (FEE, 2015, texto digital). 
Figura 1 - Mapa das Microrregiões do Vale do Taquari

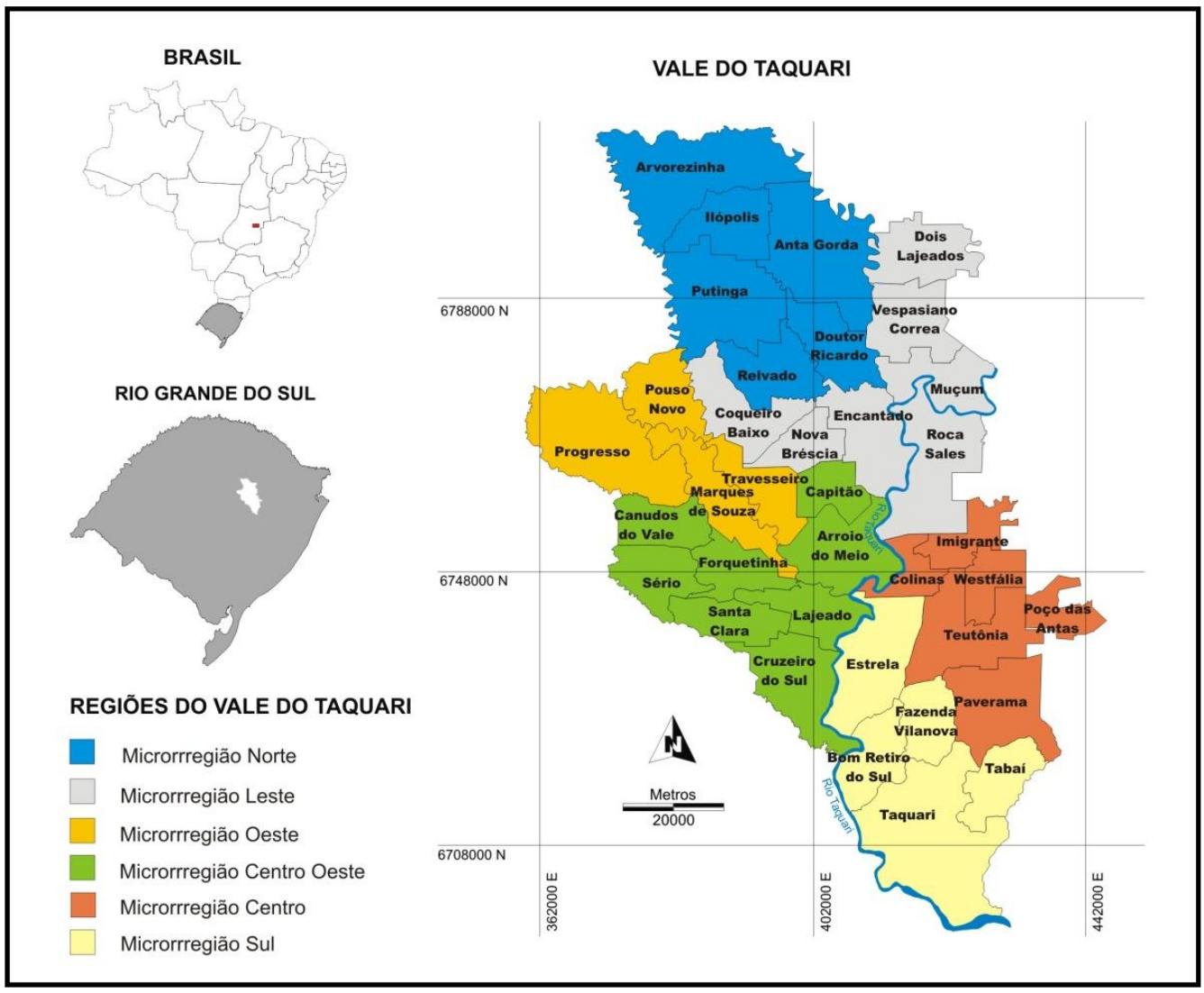

Fonte: Trombini; Kreutz, 2017, Adaptado a partir do Projeto Desenvolvimento Econômico e Sociocultural na Região Vale do Taquari/Univates.

As microrregiões do Vale do Taquari apresentam especificidades econômicas e socioculturais, isto é, existem desde pequenas propriedades rurais voltadas ao setor primário até áreas urbanizadas e industrializadas. Nas propriedades rurais do Vale do Taquari, que possuem, em média, 17 hectares, desenvolvem-se atividades relacionadas à produção leiteira, suínos, agricultura, criação de aves, piscicultura, além de reflorestamento, produção de fumo, fruticultura, criação de gado de corte e fruticultura com percentuais menores (CYRNE, 2015).

Conforme Karam (1992), nas colônias de Conde d’Eu, Caxias, Dona Isabel, Alfredo Chaves e Estrela, já não havia mais terras a serem ocupadas para atender às demandas de estabelecer os imigrantes que chegavam. Em 1854, a Empresa de Colonização Batista Fialho \& Cia instalou-se na colônia Conventos, hoje Lajeado, e iniciou, na subida do Rio Taquari, em 1867, as medições de terras mais ao norte, que seriam ocupadas pelos imigrantes. Outras companhias particulares também tiveram terras próximas ao Rio Taquari, como as de Bastos \& Irmão e Teschner \& Cia.

Assim, no Vale do Taquari e em regiões próximas, houve a expansão e o povoamento 
através de núcleos oficialmente reconhecidos pelo governo provincial, como Guaporé e Anta Gorda. Outras regiões também foram fundadas pela iniciativa privada, como, por exemplo, Arvorezinha, próximo a Soledade. Sendo assim, o governo desejava ampliar as áreas de colonização e criou uma comissão técnica para fazer um levantamento das áreas territoriais. As medições oficiais de terras particulares procederam à demarcação de lotes coloniais para os colonos que seriam assentados pelo governo.

Na segunda metade do século XIX, a região atualmente denominada de Vale do Taquari passou por diversas transformações relativas à divisão político-administrativa. Foi criado, em 1849, o município de Taquari, o primeiro que compôs a atual região do Vale do Taquari, desmembrado de Triunfo. Em seguida, foi criado o município de Estrela, em 1876, e a Vila Lajeado, em 1891 (AHLERT; GEDOZ, 2001).

Entre 1891 e 1914, os imigrantes italianos ocuparam terras no Vale do Taquari, comprando-as de companhias colonizadoras, tais como a Klenze e Cia, Bastos \& Companhia, Batista Fialho \& Cia, Cia Colonisadora Rio-Grandense e Internationale Bergban and Industriegesellschaf (REGISTRO DE IMÓVEIS DE LAJEADO, Transcripções de Immoveis, 1896- 1914). Nesse sentido, há um documento do Registro de Imóveis de Lajeado/RS, que aponta o seguinte em relação a estas empresas:

24/03/1898 - Quatro colônias de terras: três, quatro, cinco e seis, sitas entre o "Arroio Forqueta" e "Fão". Contém, todas, 400 mil braços quadrados, confrontando pelo leste com o Arroio "Forqueta", pelo Oeste com terras de Mathias Feil e dos transmitentes, pelo sul com o Arroio "Fão" e pelo norte com terras de José Martins da Cunha e das terras da Forqueta.

Adquirinte: Hernesto Henrique Guilherme Widhholder (Porto Alegre)

Transmitente: Klenze e Cia (Porto Alegre) (REGISTRO DE IMÓVEIS DE LAJEADO, Transcripção de Immoveis - nº 03 (1894), 24/03/1898, p. 119).

Em relação ao comércio de terra no início do século XX, em áreas que correspondem a territorialidades no Vale do Taquari, na Microrregião Oeste, documentos de 1906 e 1910, que se encontram no Cartório de Registro de Lajeado, informam o seguinte:

23/11/1906 - duas e meia colônias de terras $n^{\circ} 7,8$ e 9 no Travesseiro - $1^{\circ}$ distrito. Contém 250.000 braça quadradas de superfície, tendo de frente cada colônia 210 sobre $2304 \mathrm{~m}$ de fundo, dividindo pela frente com terras que são ou foram de Joaquim Alves Xavier, nos fundos com terras que são ou foram de C. Bastos, por um lado com terras de Guilherme Schthneyer e pelo outro de José Locatelli. Adquirinte: Berticelli, Giovanno (Garibaldi)

Transmitente: João Enéias Sperb (REGISTRO DE IMÓVEIS DE LAJEADO, Transcripção de Immoveis - nº 03B (1910), 23/11/1906, p. 51).

17/11/1910 - município de Lajeado, $3^{\circ}$ registro - Fão. Uma área de terras com $822.800 \mathrm{~m}^{2}$, tudo fazendo parte do título legitimado por Francisco Mariano da Silva. 
Adquirinte: Cia Colonisadora Rio Grandense (Porto Alegre)

Transmitente: João Klein e Jacob Weber (São Luiz Conzaga) (REGISTRO DE IMÓVEIS DE LAJEADO, Transcripção de Immoveis - nº 03B (1910), 17/11/1910, p. 64).

Referente à presença de Companhias Colonizadoras nas Microrregiões Norte e Leste do Vale do Taquari, destaca-se, segundo documentação do livro de compra e venda de terras do ano de 1894 no Registro de Imóveis de Lajeado, que os imigrantes italianos adquiriram terras através das Companhias Kleuze e Cia e Teschner e Cia (REGISTRO de Immoveis n $^{\circ}$, 05/06/1894).

Um dos negociantes que mantinha grande parte de áreas territoriais do Vale do Taquari era Antônio Fialho de Vargas, que concentrava algumas glebas de terras no atual município de Muçum, Arroio do Meio e Estrela (AHLERT; GEDOZ, 2001). Karam (1992) ainda destaca que Fialho possuía terras da fazenda dos Pinheiros, localizada em áreas do atual município de Dois Lajeados.

Particulares também possuíam terras e/ou fazendas na região. Entre eles aponta-se Eduardo Palassin Guinle, que concentrava suas terras às margens do Rio Guaporé, mais ao sul; José Francisco dos Santos Pinto, no atual município de Muçum; os Irmãos Dutra e Amália Fialho de Vargas, conforme referido, concentravam terras às margens do Taquari, mais precisamente no município de Muçum (KARAM, 1992).

Segundo Frosi e Mioranza (1975), os imigrantes italianos que ocuparam a atual cidade de Encantado, em linhas gerais, vieram da Colônia Dona Isabel. E, no início do século XX, a nova Colônia Encantado iniciou sua expansão para o norte, sobre territórios que correspondem aos atuais municípios de Nova Bréscia, Putinga, Anta Gorda, Arvorezinha e Ilópolis. Com essa expansão, foi criada a colônia Anta Gorda, em 1902, localizada à margem direita do Rio Taquari, próxima a Muçum (BERGAMASCHI; GIRON, 2004). Conforme informado anteriormente, o município de Encantado tinha uma grande extensão territorial, onde atualmente situam-se os municípios de Putinga, Anta Gorda, Ilópolis, Arvorezinha, Relvado, Doutor Ricardo e Coqueiro Baixo (BERGAMASCHI, GIRON, 2004).

Referente ao município em questão, conforme mapas e documentos, as terras pertenciam a diversas pessoas físicas e companhias colonizadoras. No Arquivo Histórico do Rio Grande do Sul, há uma planta (FIGURA 2), que destaca a área de jurisdição do município de Encantado e arredores. Ferri (2007) fez uma adaptação desse mapa, destacando em negrito, a parte pertencente a Francisco dos Santos Pinto. 
Figura 2: Planta de José Francisco dos Santos Pinto, do ano de 1878.

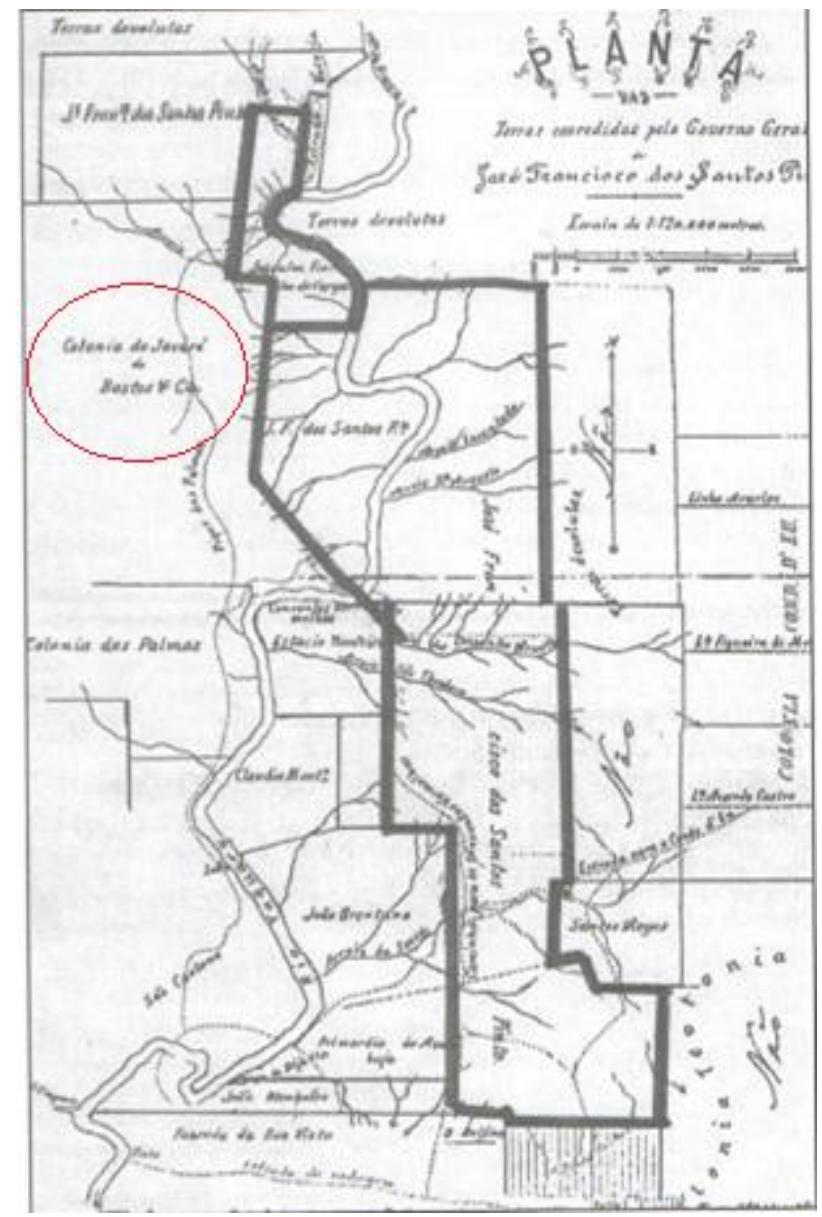

Fonte: Arquivo Histórico do Rio Grande do Sul, Terras e Colonização, 1878.

Observando a referida planta, constata-se que, em 1878, o atual município de Encantado, bem como, parte da atual cidade de Roca Sales pertenciam à Fazenda de José Francisco dos Santos Pinto. Percebe-se, ainda, que a Colônia Jacaré, (atual parte de Encantado) também consta na planta (em destaque vermelho), e já estava sob domínio da Companhia Bastos e Cia. No Registro de Imóveis de Lajeado, no livro de compra e venda de terras de 1894, há informações sobre a compra de terras próximas à Colônia Jacaré (onde, atualmente, localizam-se Linha Garibaldi, Picada Azevedo, Jacarezinho, Picada Argola, Picada Lambari e Arroio das Pedras, este último, no atual município de Nova Bréscia), por Joaquim de Carvalho Bastos, o que coincide com o mapa acima (REGISTRO de Immoveis de Lajeado, $\left.n^{\circ} 3,05 / 06 / 1894\right)$.

Segundo esse documento, a terra adquirida por Joaquim de Carvalho Bastos, em 05 de junho de 1894, localizava-se em vias fluviais e fazia limites com a Colônia Jacaré, Colônia Forqueta e áreas de terras devolutas e de particulares, conforme segue: 
[...] 18:000:000 de braças quadradas, digo metade da área de 33:492:204² e divide-se a norte com terras devolutas; ao sul com terras particulares e devolutas ao leste; com o núcleo colonial Jacaré e ao Leste com a colônia Forqueta (REGISTRO de Immoveis, 05/06/1894, p. 1).

Portanto, percebe-se que, no ano de 1894, Bastos e Cia continuam com as terras referidas. Fato relevante é que no dia seguinte ${ }^{5}$, a área da Companhia Bastos foi repassada à Companhia Colonizadora Kleuze e Cia, que logo iniciou a venda de lotes aos imigrantes e descendentes de italianos.

As terras de José Francisco dos Santos Pinto, localizadas no mapa representado na Figura 3, abrangem uma grande extensão territorial, desde Encantado até Roca Sales. Já no mapa seguinte (FIGURA 3), percebe-se que a área de Santos Pinto restringe-se à área territorial de Roca Sales, deixando de existir a de Encantado. Salienta-se que não foi possível localizar essa área, pelo fato de não encontrarmos fonte documental no Registro de Imóveis pesquisado.

Figura 3: Mapa das Terras de Francisco dos Santos Pinto, do ano de 1887.

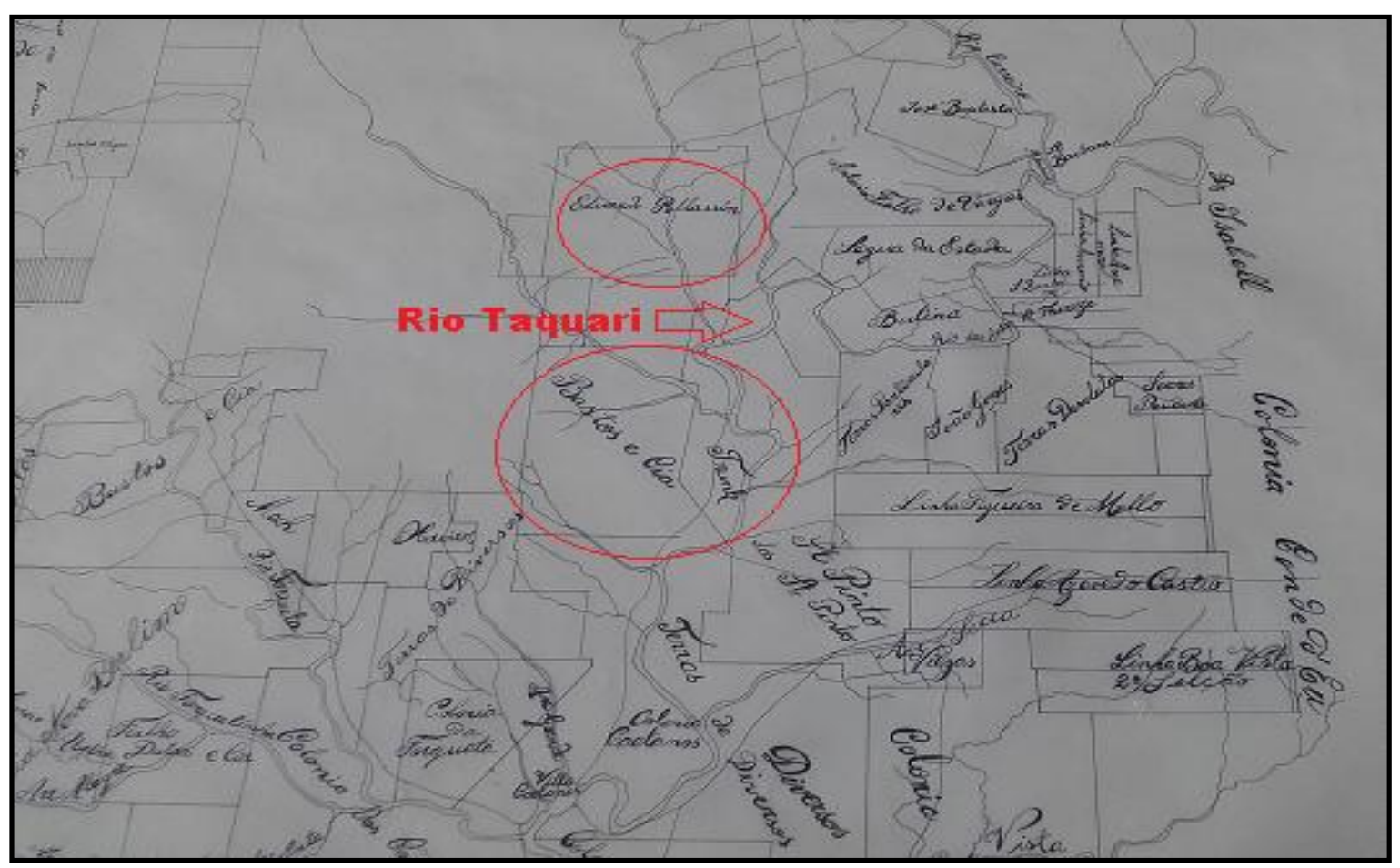

Fonte: Arquivo Histórico de Lajeado, Diversos, 1887.

Contudo, observa-se que, no Registro de Imóveis de Lajeado, há uma parte das terras de José Francisco dos Santos Pinto que permaneceu concentrada próxima às margens do Rio 
Taquari, onde, atualmente, localiza-se o centro da cidade de Encantado. Reforça esta informação o registro da venda de terras pertencentes a Francisco dos Santos Pinto, de 1894: "Vinte e nove mil e noventa braças quadradas de terras, da colônia número doze, da linha da margem direita do rio Taquary, no Encantado" (REGISTRO de Immoveis nº 3, 10/06/1897, p. 86).

Na planta anterior (FIGURA 2), constam terras de Eduardo Palassim Guinle. Acreditase, com base em Gino Ferri (2007), que pertençam a terras da atual cidade de Doutor Ricardo e da Barra do Zeferino (localidade de Doutor Ricardo). No registro de Imóveis, com data de 14 de dezembro de 1901, há referência a uma venda feita por Eduardo Palassin:

Um pedaço de terras, com a área superficial de 100.000 metros quadrados, limitando-se ao Norte e Leste com o rio Guaporé, ao Sul a linha que divide as terras dos transmittentes das do Doutor Manoel O. Postes, a oeste por uma secta a rumo N. S. até o mesmo rio (REGISTRO de Immoveis $n^{\circ} 3 A, 14 / 12 / 1901$, p. 81).

Outra Companhia presente na Microrregião Norte foi a Teschner e Cia, que se localizava nas cidades de Doutor Ricardo e Anta Gorda. Conforme dados do Registro de Imóveis de Lajeado, 24 de setembro de 1899, na localidade de Anta Gorda, há presença de solo fértil para a efetiva produção. Nesse sentido, há o seguinte registro:

Quatro colônias de mattos de cultura, sendo duas, sob ns. 19 e 20, na picada Teschner, fazendo frente a Sul e fundos a Norte e limitando-se por todos os lados com terras dos transmittentes e duas, sob ns. 4 e 8, da picada Leopoldo, fazendo frente a Sul e fundos a Norte com terras dos transmittentes, limitando-se pelo Leste e pelo Oeste com terras de Carlos Matte (REGISTRO de Immoveis $\mathrm{n}^{\circ} 3 \mathrm{~A}$, 24/09/1899, p. 37).

Referindo-se ao atual município de Doutor Ricardo, inicialmente, Linha Ricardo, também se localizou uma área de terras no Registro de Imóveis de Encantado, a de $\mathrm{n}^{\circ} 5$, com data de 19 de julho de 1915, conforme segue:

Uma área de terras da superfície de 53 hectares, 5.278 metros quadrados sob número 3 e 4, ala norte sendo a área de número 3, 26 hectares, 7232 metros quadrados e do número quatro 26 hectares, 8046 metros quadrados confrontando ao Norte com o lote número três e quatro da Linha Leopoldo, ao Sul com o Travessão do meio da [...] dita linha Ricardo, a leste com o lote número dois e a Oeste com o lote número cinco da mesma Linha Ricardo (REGISTRO de Immoveis Encantado $\mathrm{n}^{\mathbf{0}} 1$, 19/07/1915, p. 1).

Ainda, em 1901, havia, no atual município de Encantado, terras devolutas, que foram repassadas a Frederico Dexcheimer pela Companhia Jacob Ely e Nicolau Ely, na área do Arroio Jacaré, correspondentes às atuais linhas São José e Garibaldi (FERRI, 2007). O que consta no Registro de Imóveis de Lajeado, no 1036, de 30 de setembro de 1901, refere-se à 
área de matos que certamente seriam devastados pelos imigrantes e pelos descendentes de italianos, conforme se observa:

Terras de matto, com a área de $17.468 .000 \mathrm{~m}^{\circ}$ com as seguintes confrontações: ao Norte com terras de Teschner e terras de Palassin, separadas por linhas seccas; ao Sul terras de Bastos e Companhia, separadas por uma linha secca; a Leste terras de Santos Pinto, separadas por uma linha secca e terras de Theophilo de Araujo Ortiz, digo, uma linha secca; ao Oeste terras devolutas, separadas por uma linha secca e terras de Theophilo de Araujo Ortiz, separadas pelos arroios Coqueiro e Jacaré (REGISTRO de Immoveis Lajeado n 3A, 30/09/1901, p. 77).

Segundo Ferri (2007), territórios pertencentes às atuais Microrregiões Norte e Leste do Vale do Taquari estavam nas mãos de particulares, como João Batista de Mello, que concentrava suas terras em Relvado e Doutor Ricardo; Margarida Serafim Brum e Ernesto Mehring, em Anta Gorda; Miguel Mate, em Arvorezinha. A pesquisa no Registro de Imóveis de Encantado e Lajeado possibilitou observar que as terras do atual município de Putinga também se concentravam em mãos de particulares, tais como, a picada Miguelzinho, pertencente a Julio Cimadon, e a de Poço da Lage, de Angelo Cornelio de Souza Gralha.

Já os municípios de Dois Lajeados, Vespasiano Corrêa e Muçum pertenciam à Colônia Guaporé, criada em 1892, e elevada a município, em 1893. O núcleo ficava $50 \mathrm{~km}$ distante da colônia Alfredo Chaves. Guaporé foi a última colônia oficial da imigração italiana no sul do Brasil. Acredita-se que foi criada devido ao crescimento demográfico nas antigas colônias, o que promoveu um deslocamento de imigrantes e de descendentes de italianos para novos territórios (FROSI; MIORANZA, 1975).

Segundo Tedesco e Balbinot (2015), a delimitação da Colônia Guaporé perpassa os rios Carreiro, Guaporé e Taquari, conforme se pode observar no mapa a seguir (FIGURA 4). Localizada na Serra Geral, apresenta relevo bastante acidentado, com a presença de estradas irregulares e vias fluviais com quedas de água e correntezas, fatores que dificultavam o escoamento de produtos por via marítima. Entretanto, o relevo altera-se quando chega às margens do Rio Taquari, o que permitia o desenvolvimento de grande atividade portuária, em especial no Porto de Muçum, que teve, durante quase um século, grande circulação de pessoas e produtos. 
Figura 4: Mapa da colônia Guaporé.

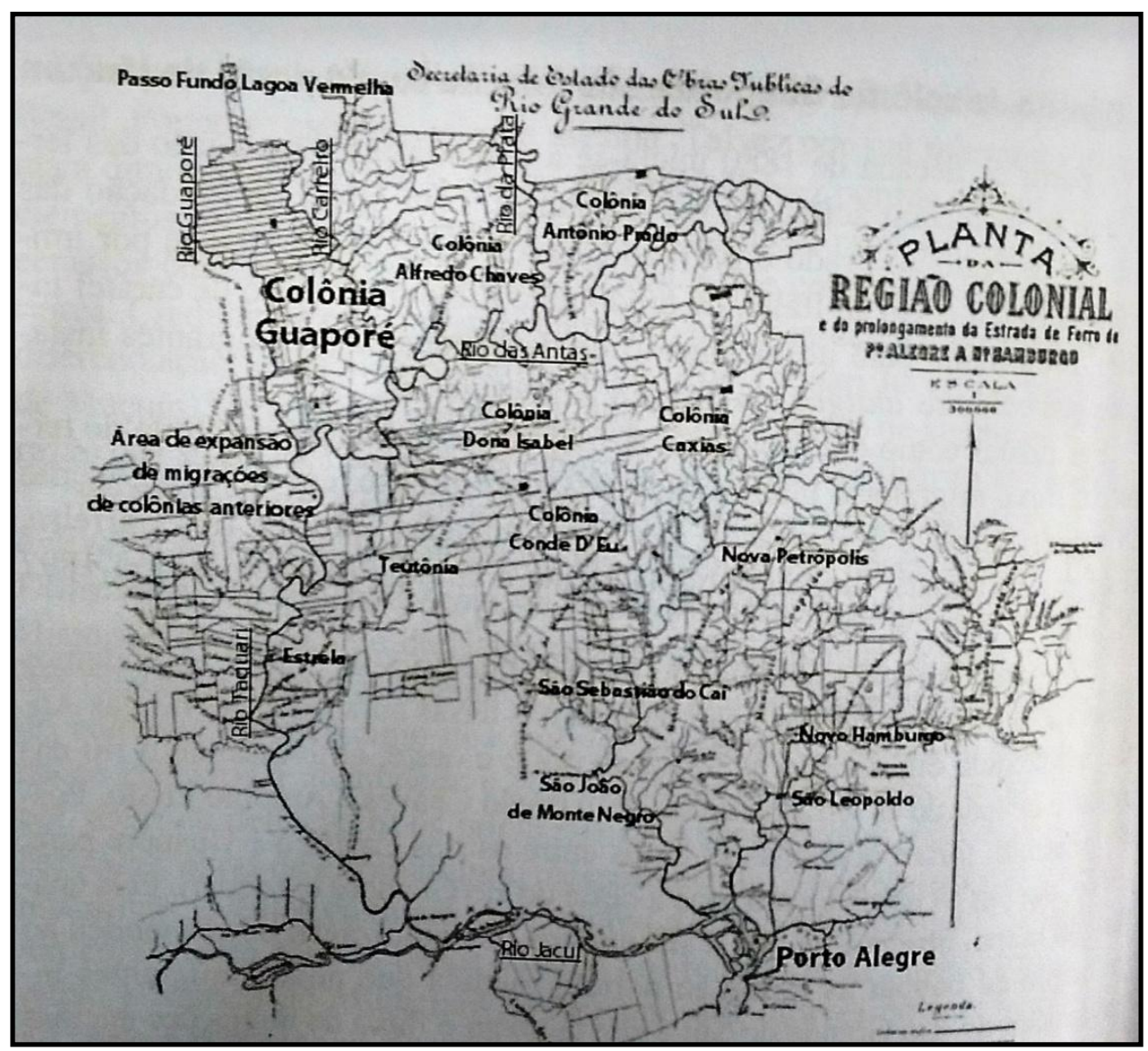

Fonte: Tedesco; Balbinot (2015, p. 220).

Em 1854, conforme Karam (1992), a Empresa de Colonização Baptista, Fialho e Cia. havia se instalado na Colônia Conventos, atual município de Lajeado. Entretanto, em 1867, um dos sócios subiu o Rio Taquari, fazendo medições de terras em territórios da futura Colônia Guaporé. 
Figura 5 - Mapa Colônia Guaporé, cidade de Muçum e Vespasiano Corrêa (s/d).

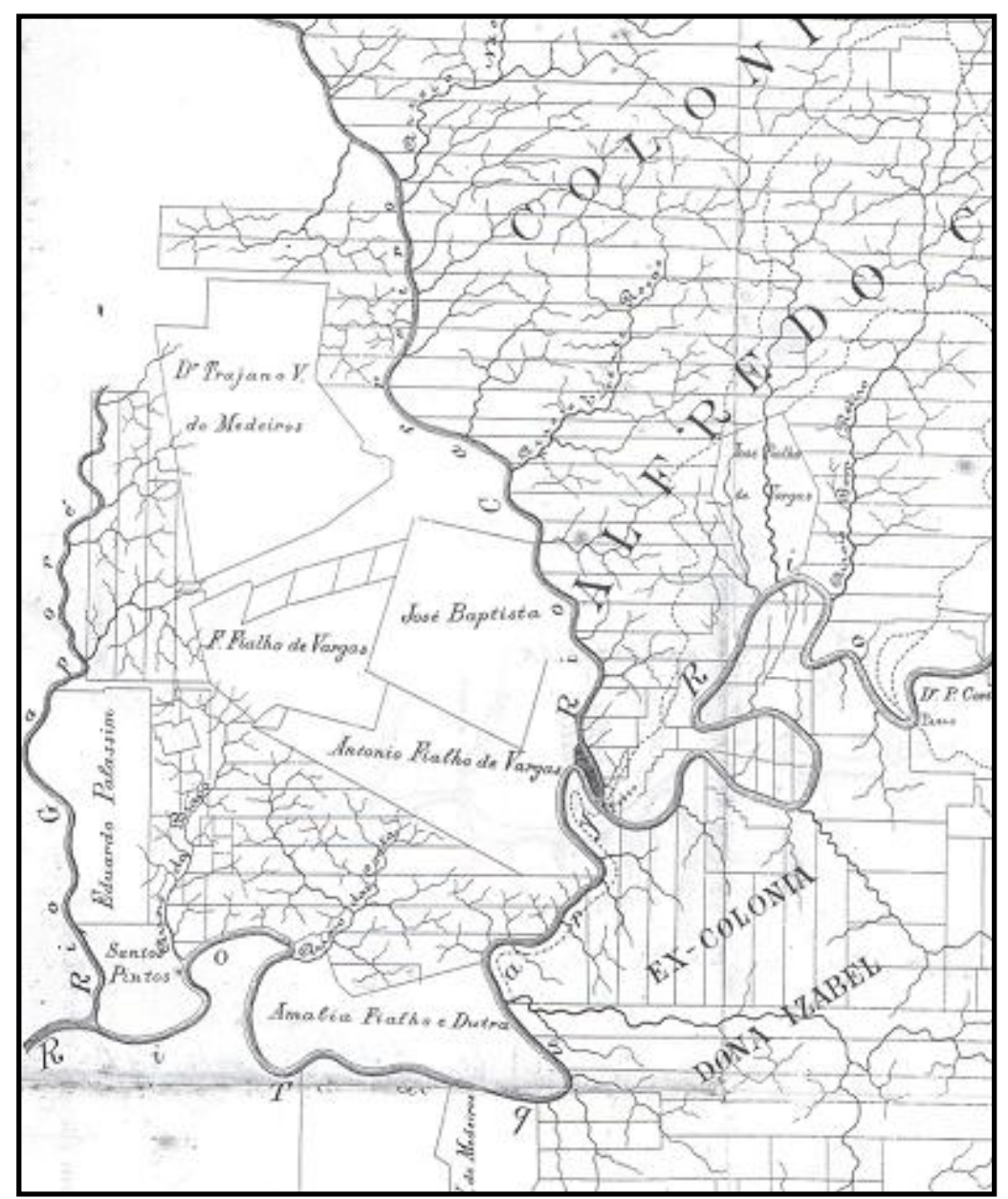

Fonte: Karam (1992, p. 68).

Parte das terras do atual município de Muçum pertenciam a Antônio Fialho de Vargas, conforme se pode identificar no mapa (FIGURA 5). No Registro de Imóveis de Lajeado, em relação à delimitação desse território consta o seguinte:

Umas terras de matos no lugar denominado "Mussum", no município de Lageado, contendo a área superficial de dois milhões de braças quadradas; e fazem frente a Leste com o rio Taquary, ao Norte com terras que foram do governo, medidas a comando Schaefer, dividindo pelo Oeste com o travessão (?) divide as terras de Santos Pinto ou Fialho; sul com o arroio Guaporé REGISTRO de Immoveis Lajeado no $3,02 / 04 / 1895$, p. 14).

Vale salientar o papel dos rios e arroios na demarcação desses territórios, pois, sem a presença desses recursos naturais, seria difícil a ocupação do território naquele período. Também serviam como marcos divisórios de áreas e para o escoamento de produtos. 
Além de Fialho, outros particulares também possuíam grande parte do território do atual município de Muçum, entre os quais podemos apontar Eduardo Palassin Guinle, o Coronel José Francisco dos Santos Pinto e os irmãos Manoel, Francisco e Saturnino Dutra. Também havia pequenas áreas devolutas pertencentes ao governo, conforme o mapa anterior (FERRI, 1988).

A picada Boa Esperança, atual município de Vespasiano Corrêa, foi datada no ano de 1896. Depois, foi denominada somente Esperança, até tornar-se $4^{\circ}$ distrito de Guaporé, em 1907, sendo colocada a denominação definitiva de Vespasiano Corrêa (FERRI, 1988). Conforme o mapa anterior (FIGURA 5), uma parte do território de Vespasiano Corrêa pertencia a Antônio Fialho de Vargas. A estrada que ligava Muçum a Vespasiano Corrêa era chamada de Estrada do Fialho, situação que ilustra a abrangência de posses no território desse proprietário.

Além dele, Eduardo Palassin Guinle, em 1880, possuía terras em seu nome. Ainda nos dias atuais, há uma localidade com o nome de Eduardo Palassin, no município de Vespasiano Corrêa. Assim como Muçum, a colonização de Vespasiano iniciou-se em 1888, com a vinda de imigrantes e descendentes de italianos, franceses, poloneses e alemães, devido a migrações internas ou diretamente da Itália (FERRI, 1988).

Em 1870, Antônio Fialho de Vargas procedeu à legitimação da posse de terras da chamada fazenda Pinheiros, atual município de Dois Lajeados, também conhecida como Fazenda Fialho. O atual município teve uma colonização particular, através de duas procurações datadas de 2 de setembro de 1904, comprovando a venda das terras situadas na colônia “Deodorópolis”, no município de Guaporé (KARAM, 1992).

Neste mesmo parâmetro, analisa-se a perspectiva macroespacial do território, que compreende as territorialidades do Vale do Taquari desde o século XVIII até sua denominação nos dias atuais. O território pode ser compreendido, conforme Cabral (2007), por uma determinada porção da superfície terrestre que é apropriada e ocupada por um grupo humano, como um espaço entre si e seus atributos tanto naturais como sociais.

Nas últimas décadas do século XX, um novo olhar sobre o conceito de território buscou mais ênfase relacionada a um espaço decisivo de relações de poder. O espaço não tem uma dimensão espacial e temporal fixa, podendo variar de tamanho como aconteceu com os municípios pesquisados, que perpassaram por vários desmembramentos até sua emancipação total. Essa emancipação territorial pela qual os municípios passaram no final da década de 1980 possibilitou que tivessem sua organização espacial. 
Retrocedendo à época da colonização, a Província de São Pedro do Rio Grande do Sul e do território que atualmente denominamos de Vale do Taquari e os respectivos municípios pesquisados faziam parte de territórios maiores. Por volta da terceira década do século XVIII, teve início o processo de distribuição de sesmarias, definindo-se a posse da terra e do gado, com o estabelecimento de estâncias. As sesmarias eram terras devolutas que foram concedidas, primeiramente, na região que se estendia de Tramandaí aos campos de Viamão, passando por Gravataí e um pouco mais ao sul, em Rio Grande. Sendo assim, a partir da primeira metade do século XIX, o Rio Grande do Sul tinha quatro povoações: Rio Grande, fundado em 1747; Porto Alegre, fundado em 1803; Rio Pardo e Santo Antônio da Patrulha, fundados em 1809 (PESAVENTO, 1983).

Vale salientar que antes da Lei de Terras, de 1850, várias áreas particulares do Rio Grande do Sul que se estendiam nestas povoações eram chamados de "fazendas". Após esta lei, foi possível que alguns proprietários particulares, comerciantes de terras, loteassem e vendessem grandes quantidades de terras para a colonização particular. Em decorrência da decadência que algumas destas fazendas passaram a enfrentar, as Companhias Colonizadoras começaram a adquirir terra por meio da compra e a transformá-las em colônias (VEDOY, 2015).

No mapa (FIGURA 6), observam-se os territórios que atualmente fazem parte da jurisdição do Vale do Taquari, a presença das principais companhias colonizadoras que vendiam terras para os colonos imigrantes italianos que chegavam. 
Figura 6 - Territorialidade do Vale do Taquari e as Companhias Colonizadoras

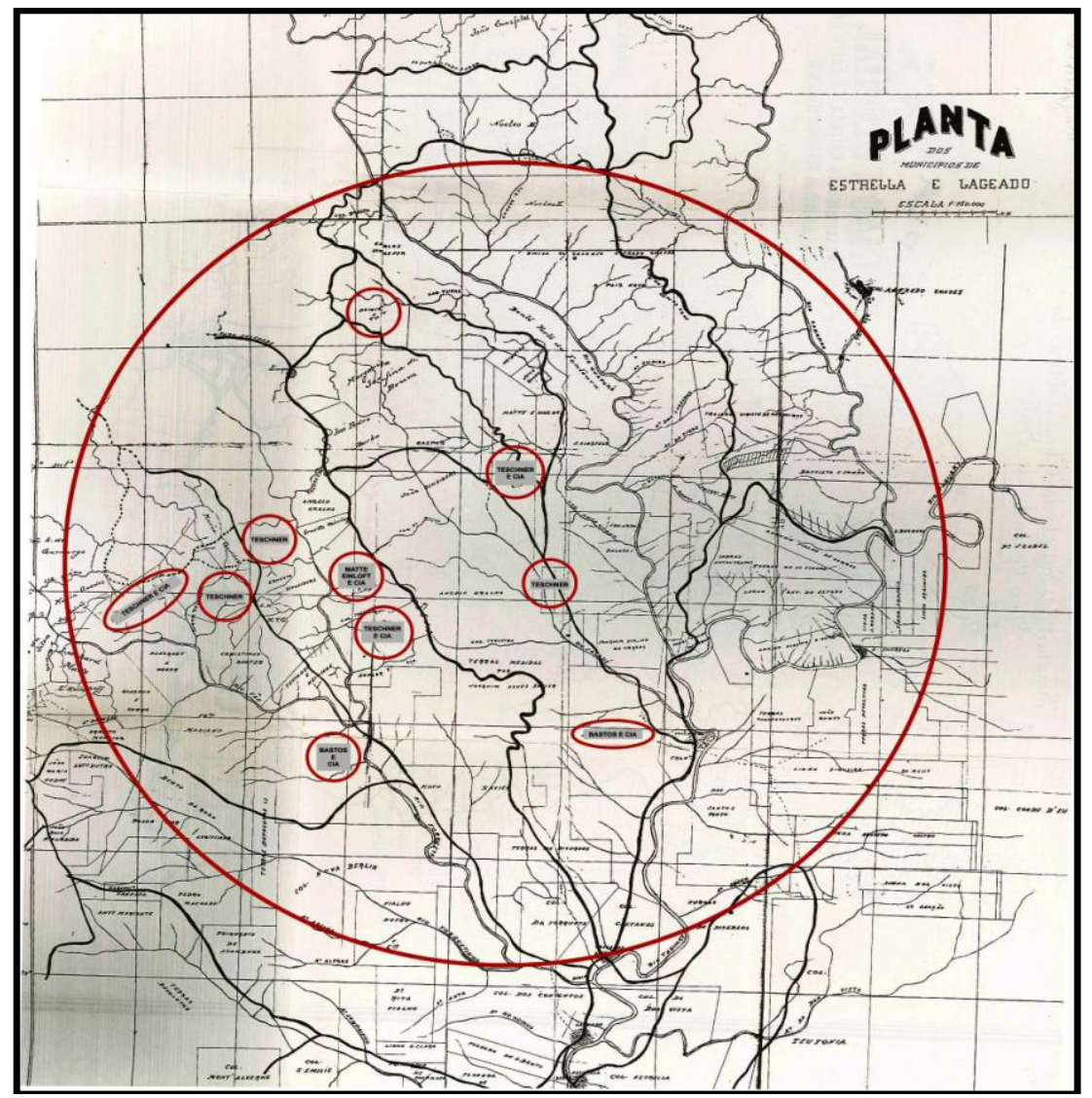

Fonte: Mapa adaptado a partir de Karam (1992).

Com base nos dados arrolados, constata-se que a atual Região do Vale do Taquari contou com Companhias Colonizadoras, tais como: Tchener, Cia Colonisadora RioGrandense e Cia e Bastos que negociou terras de particulares. Essas Companhias Colonizadoras possibilitaram fluxos migratórios, trocas culturais e intensificaram as relações econômicas e sociais dos imigrantes italianos e de seus descendentes e demais ocupantes da região.

\section{Considerações Finais}

Os italianos chegaram ao Brasil e, a partir de 1875, ao Rio Grande do Sul, onde ocuparam o território da Encosta Superior do Planalto, mais precisamente áreas localizadas entre os rios Caí e Antas. A partir das primeiras colônias de imigrantes italianos fundadas na Região Nordeste do Rio Grande do Sul, ocorreram migrações internas, pois a ocupação de todos os lotes e a utilização intensa das terras para a produção agrícola, muitas vezes, 
comprometia a fertilidade dos solos. Esses fatores favoreceram a procura de novas terras pelos imigrantes italianos, como é o caso de áreas no Vale do Taquari. Vale salientar que o principal rio da Bacia hidrográfica Taquari-Antas, o Rio Taquari, foi fundamental para o deslocamento dos imigrantes italianos e de seus descendentes, bem como, para o escoamento econômico produzido nas Microrregiões que compõem o território.

Conforme visto, a intermediação deste processo ocorreu por meio das Companhias Colonizadoras, que eram responsáveis por administrar a compra e a venda dos lotes territoriais, como é o caso das áreas demarcadas na atual região do Vale do Taquari. As companhias colonizadoras foram mecanismos relevantes para o direcionamento da população na atual região do Vale do Taquari. A grande fertilidade do solo da região foi um dos motivos que levou os colonos a se tornarem proprietários das terras, com o objetivo de desenvolver suas produções.

As principais companhias colonizadoras que comercializavam terras no Vale do Taquari aos imigrantes italianos e seus descendentes eram: Tchener, Cia Colonisadora RioGrandense e Cia e Bastos. Os documentos analisados ainda possibilitam constatar que, desde o final do século XIX até meados do século XX, tais companhias comercializaram terras no Vale do Taquari. Contudo, há outras terras que permaneceram em mãos de particulares, a exemplo de José Francisco dos Santos Pinto e Eduardo Palassin Guinle, as quais deram origem a municípios atuais como é o caso de Muçum e Dois Lajeados.

Assim sendo, constata-se que as companhias colonizadoras atuaram de forma direta na compra e na venda de terras e não foram criadas por meio de fatos isolados, mas de um processo mais amplo envolvendo a instalação de imigrantes e de seus descendentes por territórios do Rio Grande do Sul e do Vale do Taquari.

\section{Notas}

\footnotetext{
${ }^{1} \mathrm{O}$ estudo insere-se no Projeto de Pesquisa "Identidades étnicas em espaços territoriais da Bacia Hidrográfica do Taquari-Antas/RS: história, movimentações e desdobramentos socioambientais" do PPG em Ambiente e Desenvolvimento e conta com auxílios financeiros da Universidade do Vale do Taquari - UNIVATES e da FAPERGS.

${ }^{2}$ Segundo Aguiar (2009), a região hoje conhecida como Vale do Taquari é uma conotação recente, atribuída pós Constituição de 1988, na qual foram criados os Conselhos Regionais de Desenvolvimento - COREDES - que se tornaram a divisão regional oficial do Estado. Antes deste, o território do Vale era determinado em duas regiões, sendo elas região Colonial Alto Taquari (Anta Gorda, Arvorezinha, Casca, David Canabarro, Fontoura Xavier, Guaporé, Ilópolis, Nova Araçá, Nova Bassano, Nova Prata, Paraí, Putinga e Serrafina Corrêa) e região Colonial do baixo Taquari (Arroio do Meio, Bom Retiro do Sul, Cruzeiro do Sul, Encantado, Estrela, Lajeado, Muçum, Nova Bréscia e Roca Sales). AGUIAR, Daniel S. et al. Do desenvolvimento ao desenvolvimento territorial
} 
sustentável: os rumos da região do Vale do Taquari no início do século XXI. Análise. Porto Alegre, v. 20, n.1, jan/jun 2009. p. 84-102.

${ }_{3}^{3}$ As companhias particulares, em sua maioria, eram gerenciadas por descendentes de imigrantes europeus como alemães, italianos e portugueses e as oficiais eram comandadas pela província. A venda das terras era permitida e facilitada pela legislação republicana e não respeitava áreas florestais, tampouco reservas indígenas. Como existiam muitos compradores, as terras podiam ser compradas e vendidas, favorecendo a estrutura fundiária do estado (GIRON; CORSETTI, 1990). GIRON, Loraine Slomp; CORSETTI, Berenice. As companhias de colonização - A reprodução do sistema colonial. In: BONI, Luis A. de (Org.). Presença italiana no Brasil. v. 2. Porto Alegre: EST; Torino: Fondazione Giovanni Agnelli, 1990. p. 483-502.

${ }^{4}$ O termo Bacia Hidrográfica conforme o estudo de Arruda (2001, p. 212), "Trata-se, então, de uma unidade de relevo, que possui uma delimitação física bastante precisa, determinada pelo sentido do fluxo das águas, superficiais e subterrâneas. Além disso, retemos da definição a ideia de autoajuste, no sentido de interconexão dos processos que ocorrem em uma determinada bacia de drenagem”. ARRUDA, Gilmar. Bacias hidrográficas, territórios, paisagens e a história ambiental. In: Revista Porto, Natal, v. 1, p. 11-32, 2011.

${ }^{5}$ Portanto, percebe-se que, no ano de 1894, Bastos e Cia continuam com as terras referidas. Fato relevante é que no dia seguinte, a área da Companhia Bastos foi repassada à Companhia Colonizadora Kleuze e Cia, que logo iniciou a venda de lotes aos imigrantes e descendentes de italianos. REGISTRO de Immoveis de Lajeado de 05/06/1894. Transcripção de Immoveis no 3, ano 1894. Rural. ${ }^{\circ} 5$ de 5 de junho de 1894, p. 1.

\section{Referências bibliográficas}

AHLERT, Lucildo; GEDOZ, Sirlei T. Povoamento e desenvolvimento econômico na região do Vale do Taquari, Rio Grande do Sul - 1822 a 1930. Estudo \& Debate, Lajeado, ano 8, n. 1, p. 49-91, 2001.

ARQUIVO Histórico do Rio Grande do Sul. Livro da Estatística dos Immigrantes que entraram na província do Rio Grande do Sul durante o ano de 1888 e seguiram as localidades que se destinaram. c193, 1888.

ARRUDA, Gilmar. Bacias hidrográficas, territórios, paisagens e a história ambiental. In: Revista Porto, Natal, v. 1, p. 11-32, 2011.

BARTH, Fredrik. Os grupos étnicos e suas fronteiras. In:

O guru, o iniciador e outras variações antropológicas. Rio de Janeiro: Contra Capa Livraria, 2000. p. 25-67.

BEIGUELMAN, Paula. A crise do escravismo e a grande imigração. São Paulo, Brasilioise, 1985.

BERGAMASCHI, Heloisa. Eberle; GIRON, Loraine Slomp. Terra e Homens: Colônias e colonos no Brasil. Caxias do Sul: EDUCS, 2004.

BRASIL. Assembléia Geral. Lei no 504, de janeiro de 1854. Disponível em: <https://www.planalto.gov.br/ccivil_03/decreto/historicos/dim/dim1318.htm>. Acesso em: 4 nov. 2016.

BRASIL. Assembléia Geral. Lei $\mathbf{n}^{\mathbf{0}}$ 601, de 18 de setembro de 1850. Disponível em: $<$ http://www.camara.leg.br/Internet/InfDoc/conteudo/colecoes/Legislacao/Legimp-

36_26.pdf\#page=10>. Acesso em: 4 nov. 2016.

CABRAL, Luiz Otávio. Revisando as noções de espaço, lugar, paisagem e território, sob uma perspectiva geográfica. Revista de Ciências Humanas, Florianópolis, EDUFSC, v. 41, n. 12, p. 141-155, abr./out. 2007.

COSTA, Rovílio. Imigração italiana no Rio Grande do Sul. 2. ed. Caxias do Sul: EST/EDUCS, 1986.

CYRNE, Candido da Silva. Indicadores de gestão em propriedades produtoras de leite do Vale do Taquari/RS: um estudo comparativo com as propriedades da região da Galícia/Espanha. 220 f. Tese (Doutorado em Ambiente e Desenvolvimento) - UNIVATES, 
Lajeado, 2015.

DE BONI; Luis A.; COSTA, Rovílio. Far la América: a presença italiana no Rio Grande do Sul. Porto Alegre, Rioceli, 1991.

FAVARO, Cleci Eulália. Os "italianos": entre a realidade e o discurso. In: BOEIRA, Nelson; GOLIN, Tau (Coord.). História Geral do Rio Grande do Sul. Passo Fundo: Méritos, v. 2 Império, p. 301-319, 2006.

FERRI, Gino. Muçum: princesa das pontes. Caxias do Sul: prefeitura Municipal de Muçum. 1988.

FERRI, Gino. Encantado II: sua história, sua gente. Encantado: AJP, 2007.

FREITAS JÚNIOR, Augusto Teixeira. Terras e colonização: anotados e editados por TFJ Rio de Janeiro: Garnier, 1882.

FROSI, Vitalina Maria; MIORANZA, Ciro. Imigração italiana no nordeste do Rio Grande do Sul: processos de Formação e Evolução de uma Comunidade Ítalo-Brasileira. Porto Alegre: Movimento, 1975.

FUNDAÇÃO DE ECONOMIA E ESTATÍSTICA - FEE. Governo do Estado do Rio Grande do Sul $\quad$ d $\quad$ RS. 2013. Disponível em: <http://www.fee.rs.gov.br/perfilsocioeconomico/coredes/detalhe/corede=Vale+do+Taquari $>$ Acesso em 01 de julho de 2015.

GIRON, Loraine Slomp; HERÉDIA, Vania. História da imigração italiana no Rio Grande do Sul. Porto Alegre: EST Edições, 2007.

GIRON, Loraine Slomp; CORSETTI, Berenice. As companhias de colonização - A reprodução do sistema colonial. In: BONI, Luis A. de (Org.). Presença italiana no Brasil. v. 2. Porto Alegre: EST; Torino: Fondazione Giovanni Agnelli, 1990. p. 483-502.

HERÉDIA, Vânia Beatriz Merlotti. Contexto histórico da Itália antes da unificação. In: RIBEIRO, Cleodes Maria Piazza; POZENATO, José Clemente. (Orgs). Cultura, Imigração e Memória: percursos e horizontes, 25 anos do ECIRS. Caxias do Sul: EDUCS, 2004. INSTITUTO BRASILEIRO DE GEOGRAFIA E ESTATÍSTICA - IBGE. Projeto de divisão regional do Brasil em mesorregiões e microrregiões geográficas. [S.1.], 2008.

IOTTI, Luiza Horn. O olhar do poder: a imigração italiana no Rio Grande do Sul, de 1875 a 1914, através dos relatórios consulares. Caxias do Sul: EDUCS, 1996.

IOTTI, Luiza Horn (Org.). Imigração e colonização: legislação de 1747-1915. Porto Alegre: Assembléia Legislativa do Estado do RS: Caxias do Sul: EDUCS, 2001.

HAESBERT, Rogério. Região, regionalização e regionalidade: questões contemporâneas. Antares (Letras e Humanidades), Caxias do Sul, n. 3, jan./jun. 2010.

KARAM, Elaine Maria Consoli. Raízes da Colonização: em destaque a Colônia Guaporé e o município de Dois Lajeados. Porto Alegre: CORAG, 1992.

LANDO, Aldair M; BARROS, Eliane C. Capitalismo e Colonização - os alemães no Rio Grande do Sul. In: DACANAL, José H; GONZAGA, Sergius. RS: imigração e colonização. Porto Alegre: Mercado Aberto, 1996. p. 9-33.

LEVI, Giovanni. Sobre a Micro-História. In: BURKE, Peter (org.). A escrita da História: Novas Perspectivas. São Paulo: Editora da Universidade Estadual Paulista, 1992.

MANFROI, Olívio. A colonização italiana no Rio Grande do Sul: implicações econômicas, políticas e culturais. 2. ed. Porto Alegre: EST, 2001.

MAPA da Colônia Guaporé. A colônia Guaporé, o porto fluvial de Muçum e as companhias de navegação: nordeste do RS - 1982-1950. In: TEDESCO, João C; NEUMANN, Rosane M. (org.). Colonos, colônias e colonizadoras: aspectos da territorialização agrária no Sul do Brasil. Porto Alegre: Letra\&Vida, 2015. p. 217- 245.

MAPA das Terras de Francisco dos Santos Pinto do ano de 1887 - Mappa do Municipio da 
Estrella com as modificações necessárias as suas actuaes divisas 1887 - Planta das terras concedidas pelo Governo Geral a José Francisco dos Santos Pinto. Arquivo Histórico de Lajeado. 1887. Escala 1:160.000.

MOREIRA, Ruy. Pensar e ser em Geografia. São Paulo: Contexto, 2007.

PESAVENTO, Sandra. RS: Agropecuária colonial e industrialização. Porto Alegre: Mercado Aberto, 1983.

PLANTA de José Francisco dos Santos Pinto do ano de 1878 - Propício, J. Planta das terras concedidas pelo Governo Geral a José Francisco dos Santos Pinto. Arquivo Histórico do Rio Grande do Sul. 1878. Escala 1:120.000.

REGISTRO de Immoveis Encantado de 19/07/1915. Transcripção de Immoveis $\mathrm{n}^{\circ}$ 1, ano 1915. Linha Ricardo. $n^{\circ}$ 5, de 19 de julho de 1915, p. 1.

REGISTRO de Immoveis de Lajeado de 05/06/1894. Transcripção de Immoveis $\mathrm{n}^{\circ} 3$, ano 1894. Rural. $\mathrm{n}^{\circ} 5$ de 5 de junho de 1894 , p. 1.

REGISTRO de Immoveis Lajeado de 02/04/1895. Transcripção de Immoveis nº 3, ano 1894. Terras no Mussum. $\mathrm{n}^{\mathrm{o}} 76$ de 2 de abril de 1895, p. 14.

REGISTRO de Imóveis Lajeado de 10/06/1897. Transcripção de Immoveis nº 3, ano 1894. Terras. $\mathrm{n}^{\circ} 387$ de 10 de junho de 1897, p. 86.

REGISTRO de imóveis. Transcripção de Immoveis $n^{\circ} 3$, ano 1894. Quatro colônias de terras, n. 530, 24 mar. 1898. p. 119.

REGISTRO de Immoveis Lajeado de 24/09/1899. Transcripção de Immoveis $\mathrm{n}^{\circ} 3 \mathrm{~A}$, ano 1898. Anta Gorda. $n^{\circ} 842$ de 24 de setembro de 1899, p. 37.

REGISTRO de Immoveis Lajeado de 30/09/1901. Transcripção de Immoveis $\mathrm{n}^{\circ} 3 \mathrm{~A}$, ano 1898. Arroio Jacaré. no 1036 de 30 de setembro de 1901, p. 77.

REGISTRO de Immoveis Lajeado de 14/12/1901. Transcripção de Immoveis $\mathrm{n}^{\circ} 3 \mathrm{~A}$, ano 1898. Margem direita do Rio Guaporé. $\mathrm{n}^{\circ} 1052$ de 14 de dezembro de 1901, p. 81.REGISTRO DE IMÓVEIS. Transcripção de Immoveis $\mathrm{n}^{\circ} 3 \mathrm{~B}$, ano 1906. Duas e meia colônias de terras $\mathbf{n}^{\mathbf{0}} \mathbf{7 , 8 , 9}$ no Travesseiro, n 1446, 23 nov. 1906. p. 51.

REGISTRO DE IMÓVEIS. Transcripção de Immoveis $\mathrm{n}^{\circ}$ 3B, ano 1910. Município de Lajeado, $3^{\circ}$ distrito - Fão, n. 1826, 17 nov. 1910. p. 64.

REVEL, Jacques. Micro-história, macro-história: o que as variações de escala ajudam a pensar em um mundo globalizado. Revista Brasileira de Educação, Rio de Janeiro, v. 15, n. 45, p. 434-590, set/dez. 2010.

TEDESCO, João Carlos; BALBINOT, Giovani. A colônia Guaporé, o porto fluvial de Muçum e as companhias de navegação: nordeste do RS - 1982-1950. In: TEDESCO, João C; NEUMANN, Rosane M. (Org.). Colonos, colônias e colonizadoras: aspectos da territorialização agrária no Sul do Brasil. Porto Alegre: Letra\&Vida, 2015. p. 217-245.

TROMBINI, Janaíne. KREUTZ, Marcos. Mapa com a localização das Microrregiões do Vale do Taquari. 2015. Adaptação a partir do mapa do acervo do Projeto Desenvolvimento Econômico e Sociocultural na Região Vale do Taquari. Lajeado. Univates.

TROMBINI, Janaíne; KREUTZ, Marcos. Mapa com áreas de colonização no Vale do Taquari. Adaptação a partir do mapa do acervo do Projeto Desenvolvimento Econômico e Sociocultural na Região Vale do Taquari. Lajeado: Univates, 2015.

VEDOY, Moisés Ilair Blum. Contatos interétnicos: sesmeiros, fazendeiros, imigrantes alemães e indígenas Kaingang em territórios das bacias hidrográficas do Taquari-Antas e Caí. 2015. 100 f. Monografia (Graduação) - Curso de História, Centro Universitário UNIVATES, Lajeado, 2015. 